\title{
Far East Film festival, Udine
}

\author{
By Yvonne Ng
}

Spring 2002 Issue of KINEMA

\section{INTERVIEW WITH FEDERICA DINI, FAR EAST FILM, UDINE, ITALY}

Federica Dini served as Secretarial Editor of the third edition of Far East Film festival (April 2001). She spoke to Kinema's Yvonne Ng.

Kinema: It seems rather unusual to have a festival concentrating fully on Asian cinema here in Udine. How did the Far East Film festival come about?

Federica Dini: Actually, the festival started fifteen years ago. It was and is still called the Udineincontri Cinema. It was only recently that we decided to focus on Far East cinema. Since its beginning, the festival has concentrated on popular cinema. So one year, you would have European westerns, the following year, Italian cinema of the 1950s and so on. It was a theme festival, and the subject matter changed every year. But in 1998, we programmed Far East cinema for the first time and it was called Hong Kong Film. We portrayed fifty years of Hong Kong cinema and invited well-known filmmakers and stars such as Ringo Lam, Johnny To, Anita Yuen, Cha Chuen-Yee, Peter Chan and many others. That was the beginning. Because it was so successful, we decided to broaden our horizons and include other Far East countries. So the following year, we changed the festival theme Hong Kong Film slightly and it became the first edition of Far East Film in 1999. We "discovered", so to speak, countries such as South Korea, Thailand and Singapore. Again, we were very successful, so we decided to continue on this path.

The aim is to have a broad panorama of popular Asian movies every year. What we want to present to the European public are the latest productions from the Far East but they have to be popular because in all other festivals, what you tend to see are only art-house movies, and here are what ordinary people see every day in Asia. We thought it would be a good idea to present this type of film and we hope more and more distributors will understand how potentially interesting they are and try to find a new market for them.

\section{Who makes up the audience for the Far East Film?}

When we started, we didn't know what the reaction of the public would be because it was the first time we were presenting so many Far East movies in their original languages. But we always provide translation through earphones into Italian for the Italian public who cannot understand English, Cantonese or Mandarin. So the films are in their original languages with subtitles in English and with Italian translation.

In the beginning we thought the festival would only interest people from a certain sector, a minority who would like Far East Asian movies. But then we discovered that the general public enjoyed the movies as well. In fact, the public has been growing with each festival and I think the audience has come to realize that it's not only gongfu films that are being produced in the Far East. The general idea before was, oh, Far East Asian movies, it's all gongfu, martial arts and that's it. They might perhaps know something about Bruce Lee, Jackie Chan or maybe John Woo but that's it. We wanted to show that the Far East also produces loves stories - very good ones - melodramas, and many other genres.

There are some screenings which are attended by teenagers and even children sometimes. We had Lotus Lantern which was an animated film from China and there was a very large audience of teenagers and young children. It's good for our European public and it's also good for the Far East Asian communities living in Italy because they know Udine is the place to be if they want to see some of the movies. It's rather moving at times, when you see large families arriving with babies and old people. There are days when they, especially the Chinese community, close their shops and restaurants just to flock to Udine to watch the movies because otherwise, they can only see them on VCDs or VHS but not on the big screen.

The theatre has a seating capacity of 1200 people and there are times when it's all filled up. Well, we have to stress the fact that all screenings are free because our aim is to promote Far East Asian movies. Maybe part of the success is that people can come here and just walk in, but that's what we really want to keep. We have an Italian audience, the local audience from Udine but the national audience is also growing. People come here from Rome, Milan and from all over. For example, all universities who have a department in 
visual arts and cinema will usually send students over. So we have 250 students coming from Italy, Germany, France, Austria, Slovenia and now, new guests are also coming from the US, which is always good news. We have representatives from many international film festivals, from television and people working for websites. The word is spreading around, I think.

\section{What do you think attracts the Italian public to the cinema of East Asia?}

Up to now, we've always seen a lot of Hollywood movies and we didn't really know much about the other parts of the world due to problems of distribution and because people assume the language barrier would really be a problem. But our festival is trying to demonstrate how the linguistic problem can be no problem at all provided you have subtitles in English or a translation. I think there's a hunger for this kind of cinema. To us it's very fresh, very new. The way some movies are shot is interesting, the lighting and the setting of the movie can be interesting itself.

There was an initial fear that the western audience wouldn't be able to identify with the Chinese or Oriental characters on the big screen but no, the films proved that there are some universal values that are accepted by everybody. If it's a love story, it doesn't matter if the character is from China or Japan or South Korea, it's still about love and everybody can understand that. I hope we will be able to attract more distributors so they understand it's good to bring some films from the Far East and not only from Hollywood. We have nothing against Hollywood productions of course, but that's what we're used to watching. To be able to see what's happening on the other side of the world is rejuvenating.

Here in Udine, the film distribution is eighty percent Hollywood or European. The Centro Espressioni Cinematografiche (CEC) which organises this film festival is a film club that operates all year round. At CEC, we try to present independent film productions from different countries and we're the only cinema in town that does this. All the other cinemas here are commercial.

How has the festival grown over the years?

When we held the Hong Kong Film festival in 1998, we were still based at the Cinema Ferroviario which is the theatre on the other side of town. The seating capacity there is around 260 and it was always full and many a time we had to turn people away. The following year we were lucky enough to have this theatre with its seating capacity of 1200 . For the evening screenings it's always full. Last year, 30,000 people attended in one week. We had 53 movies. This year we have 73 .

The festival used to last one week in the past but this year we have nine days. The screenings start around half past nine in the morning and continue late into the night. We have some six screenings a day. Two in the morning, two in the afternoon, then at six or half past six the public gets to meet and question the guests, directors and so on, and then there are another two screenings in the evening. Because there are so many movies to show this year, we decided to add a second venue, the Cinema Ferroviario, for special sections that work well in the smaller theatre.

\section{What about the festival funding?}

The festival is funded by public money - government money, at different levels. It is sponsored partly by the central government and partly by the regional government and the town council. We also get a little help from the airlines. For instance, Cathay Pacific is helping out and so is Korean Air. This year we also have some help from local companies dealing in food and wine. It has been a bit difficult to get sponsors; I don't know why really, because we are a window to an international public and we can be a very good medium for sponsors. So sponsors are more than welcome, especially since we'll have to increase our budget if we want to keep the festival growing.

Through the festival, we also promote our region, which is why we're getting money from our regional government. They're well aware that we're bringing people from all over the world here. The minister for tourism, for example, is very happy with us. But our basic aim is to promote movies. What's also very important to us - and it's in the name of the festival - Udine Incontri which means Udine meetings, is that here, you get to meet the protagonists of the movies, the film directors, actors and actresses. They come here and give our audiences a chance to meet them, talk to them and ask questions.

At times it's really hectic because we have to face a growing number of activities. People have been working round the clock but we're really committed to what we're doing. We really love our jobs and we enjoy doing 
what we do very much. I think that's our secret. People coming to Udine realize how familiar this place is. The film directors, actors, the people attending can unwind and really feel at ease here. It's not like in Cannes or Venice where you have no time to speak to anybody and everybody's always rushing about. People who come here enjoy the atmosphere very much. When we had the Hong Kong Film festival and Ringo Lam and Johnny To came for the first time, they said it's really amazing. We all live in Hong Kong but we hardly see each other when we're there. We have to fly all the way to Udine to meet and discuss the state of cinema! I think it was very interesting, not only for us but for the filmmakers themselves to meet and discuss new trends and possibilities. I think they realized that this festival was a central meeting point for them.

\section{How much does it cost to mount this festival?}

The festival is budgeted at US $\$ 300,000$ but the real cost this year is US $\$ 330,000$. Before, we've always managed to balance the budget but this year, we've had a lot of expenditures for accommodation and flights because the number of people coming is increasing and we do not want to refuse accommodation to anybody since the more people who come, the better for us.

But of course, if we find more sponsors, it means we can bring more people over. The list of guests we had in the past four years is amazing considering how tiny Udine is. We've had many of the major stars coming from East Asia including Peter Chan, Anthony Wong, Francis Ng and Ringo Lam from Hong Kong. In 2000, our guests included Kang Soo-yeon from South Korea and René Liu from Taiwan. The Hong Kong director Johnny To came three times in a row, which was very surprising because he's working like crazy. He was one of the big discoveries of the festival. Since he came here, he's become more and more famous - it's like we brought him good luck! The problem last year was that all our guests had to fly back to Hong Kong because they were all nominated for the 2000 Hong Kong awards so we were fighting with the Hong Kong International Film Festival to have the guests here.

The sections on other countries have been growing as well. In 2000, we only had a few movies from mainland China, but this year the section for mainland China is really big - sixteen films altogether. We have developed a very good relationship with the National Chinese Film Bureau via its branch in Shanghai. So this year we are presenting eight Shanghainese films and we've been able to bring over almost all of the film directors to represent the eight movies. And for the first time also, we have a selection of eight movies from the Philippines, all in Tagalog. We've never seen a Filipino movie before, so from a social point of view, it's really new, really fresh. We've also had the help of Roger Garcia and Noel Vera, the Filipino film critic, in putting together this section. In 1999, we had director Glen Goei from Singapore to present his film Forever Fever which was a huge success at the festival. He was very friendly and charming and was able to get everyone in the audience, one thousand, two hundred people, standing up on the closing night and dancing away, Forever Fever style. It was great fun.

Hong Kong films are still at the core of the festival. This year we have about twenty movies from Hong Kong but Japanese movies are increasing too. Last year we had three from Japan but this year we are showing nine. The South Korean section is also very strong with eleven movies this year. We have also one movie from Thailand and one from Singapore, Chicken Rice War. In all, we have over 70 films this years and we're trying to broaden our horizons every year.

How does the Udine festival compare to similar festivals in Europe, for example, Deauville's Asian Film Festival in France?

I guess Deauville has much more money than we do but they have a much smaller number of movies. Deauville is just three to four days long and we are now nine days. They present some twenty movies or so and we are able to present three times this number. So our festival is bigger in terms of the numbers of movies shown and the number of people who attend although we have a much smaller budget.

The Pordenone Silent Film Festival is only about $45 \mathrm{~km}$ from Udine. Are the two festivals connected in any way?

Well, I happen to work for the other festival too! Behind the Pordenone Silent Film Festival, there are two important film institutions. One is La Cineteca del Friuli, Gemona or the Gemona Film Archive, the other is Cinemazero, Pordenone. These two organisations got together and they formed the Pordenone Silent Film Festival. The Film Archive in Gemona also collaborates with the Far East Film in Udine. For example, our 
very good collaboration with the Hong Kong Film Archive is thanks to the support of the Cineteca del Friuli. So there is a connection in the sense that the Gemona Film Archive which is part of the Pordenone Silent Film Festival also helps this festival.

\section{What are some of your thoughts regarding the future of the Far East Film festival?}

I think the festival is growing very fast, thanks to email and the internet. It is also getting more difficult to select the movies because we have to view more than one hundred and fifty films to cut down to about seventy. I think our aim in the future will be to continue on this path, to keep the festival popular, to present the latest productions from the Far East, to have more and more people attending from different countries, to have more stars and guests, including people from distribution houses because that is what really helps in the end. We get these very busy days during the festival but then people here have to wait another year until the next Far East Film festival starts again in April. We hope that one day, we'll be able to choose between a Hollywood movie and a Japanese movie but in normal theatres. Otherwise, it's like eating a big cake in one gulp and then having to fast for the rest of the year.

(Udine, Italy, April 2001)

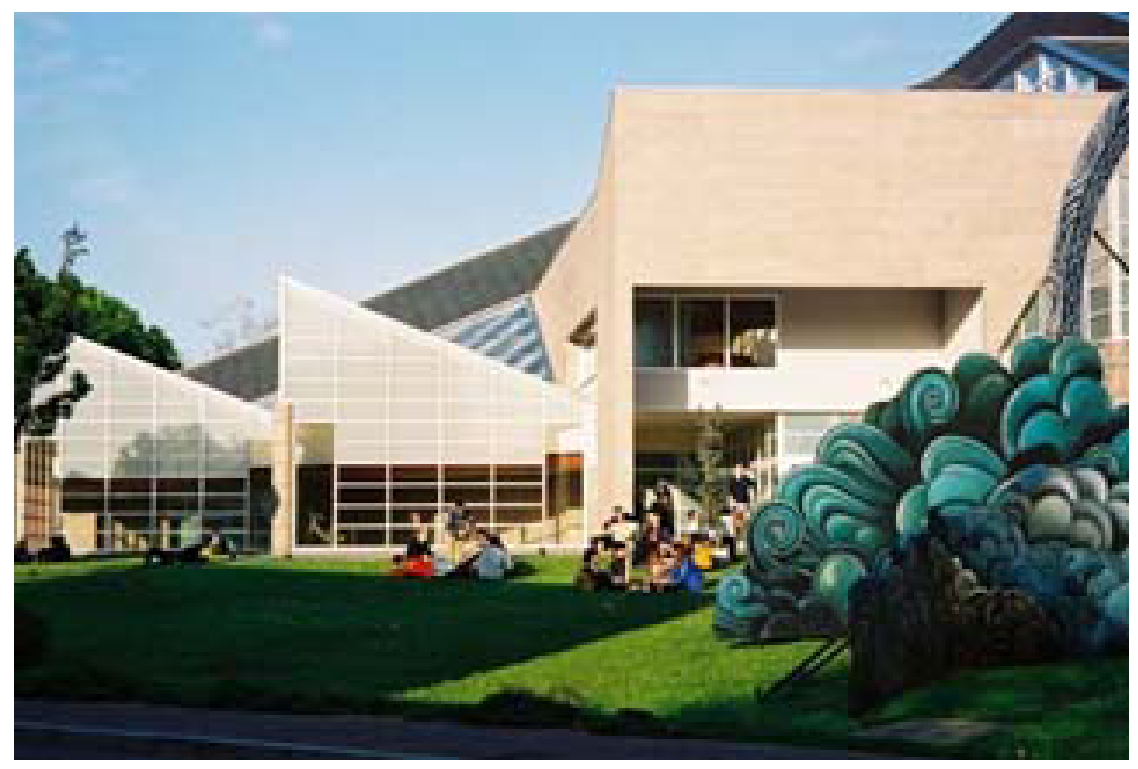

Figure 1: Far East Film festival 2001, Udine (Teatro Da Giovane)

\section{Author Information}

Yvonne NG is the co-author of Latent Images: Film in Singapore Second edition (NUS Press, 2010); Latent Images: Film in Singapore (OUP, 2000) and Latent Images: Film in Singapore CD-ROM (Singapore, 2003). She has written on Singapore and Asian cinema and contributes to the International Film Guide. 